Archaeologies of Text 


$$
\text { Joukowsky Institute Publications }
$$

1. KOINE: Mediterranean Studies in Honor of R. Ross Holloway Edited by Derek Counts and Anthony Tuck

2. Re-Presenting the Past: Archaeology through Text and Image Edited by Sheila Bonde and Stephen Houston

3. Locating the Sacred: Theoretical Approaches to the Emplacement of Religion Edited by Claudia Moser and Cecelia Feldman

4. Violence and Civilization: Studies of Social Violence in History and Prehistory Edited by Roderick Campbell

5. Of Rocks and Water: Towards an Archaeology of Place Edited by Ömür Harmanşah

6. Archaeologies of Text: Archaeology, Technology, and Ethics Edited by Matthew T. Rutz and Morag Kersel 


\section{Archaeologies of Text \\ Archaeology, Technology, and Ethics}

edited by

Matthew T. Rutz and Morag M. Kersel

Oxbow Books

Oxford and Philadelphia 
Joukowsky Institute Publication 6

General series editor: Prof. John F. Cherry

Joukowsky Institute for Archaeology and the Ancient World

Brown University, Box 1837/60 George Street, Providence, RI 02912, USA

Published in the United Kingdom in 2014 by

OXBOW BOOKS

10 Hythe Bridge Street, Oxford OX1 2EW

and in the United States by

OXBOW BOOKS

908 Darby Road, Havertown, PA 19083

Published by Oxbow Books on behalf of the Joukowsky Institute

(C) Brown University, Oxbow Books and the individual contributors 2014

Paperback Edition: ISBN 978-1-78297-766-7

Digital Edition: ISBN 978-1-78297-767-4

A CIP record for this book is available from the British Library

All rights reserved. No part of this book may be reproduced or transmitted in any form or by any means, electronic or mechanical including photocopying, recording or by any information storage and retrieval system, without permission from the publisher in writing.

Printed in the United Kingdom by Hobbs the Printers Ltd, Totton, Hampshire

For a complete list of Oxbow titles, please contact:

\section{UNITED KINGDOM}

Oxbow Books

Telephone (01865) 241249

Fax (01865) 794449

Email: oxbow@oxbowbooks.com

www.oxbowbooks.com
UNITED STATES OF AMERICA

Oxbow Books

Telephone (800) 791-9354

Fax (610) 853-9146

Email: queries@casemateacademic.com www.casemateacademic.com/oxbow

Oxbow Books is part of the Casemate Group

Front cover: Cuneiform tablet PF 0694 (see p. 17, Figure 2.3) with Elamite text on the obverse (top left) and on the reverse (top right) an impression of seal PFS 0093*, inscribed with name of Cyrus of Anzan, son of Teispes (images courtesy of Persepolis Fortification Archive Project, University of Chicago); detail (bottom) from the Greek inscription on the Rosetta Stone (EA24, (c) Trustees of the British Museum).

Back cover: Excerpt from Mayan hieroglyphic inscriptions on Copan Stela 10 (see p. 37, Figure 3.2a); drawing by Nicholas P. Carter after field sketches by David Stuart (images courtesy of Nicholas P. Carter). 


\section{Contents}

1. Introduction: No Discipline is an Island 1 Morag M. Kersel and Matthew T. Rutz

2. Case in Point: The Persepolis Fortification Archive Matthew W. Stolper

3. Space, Time, and Texts: A Landscape Approach to the Classic Maya Hieroglyphic Record Nicholas P. Carter

4. Now You See It, Now You Don't: The Dynamics of Archaeological and Epigraphic Landscapes FROM COPTIC EGYPT Scott Bucking

5. Articulating Neo-Assyrian Imperialism at Tell Tayinat Timothy P. Harrison

6. The Archaeology of Mesopotamian Extispicy: Modeling Divination in the Old Babylonian Period Matthew T. Rutz

7. The Ernest K. Smith Collection of Shang Divination Inscriptions at Columbia University and the Evidence for Scribal Training at Anyang Adam Smith

8. Tracing Networks of Cuneiform Scholarship with Oracc, GKAB, and Google Earth Eleanor Robson

9. Ancient Relationships, Modern Intellectual Horizons: The Practical Challenges and Possibilities of Encoding GreEK ANd Latin Inscriptions Lisa Anderson and Heidi Wendt

10. Forging History: From Antiquity to the Modern Period Christopher A. Rollston 
11. Wikileaks, Text, and Archaeology: The Case of the Schøyen Incantation Bowls

Neil J. Brodie and Morag M. Kersel

12. Do Restrictions on Publication of Undocumented

Texts Promote Legitimacy?

214

Patty Gerstenblith

13. Publishing Undocumented Texts: Editorial Perspectives John F. Cherry

INDEX 


\section{List of Figures}

2.1 Photograph of the site of Persepolis.

2.2 Plan of the site of Persepolis.

2.3 Elamite document from the Persepolis Fortification Archive.

2.4 Aramaic document from the Persepolis Fortification Archive.

2.5 Uninscribed, sealed document from the Persepolis Fortification Archive.

2.6 Unique Old Persian document from the Persepolis Fortification Archive.

2.7 Screenshot from the OCHRE presentation of Persepolis Fortification Archive Project.

3.1 A map of the Maya area, showing sites mentioned in Chapter 3.

3.2a Passage from Copan Stela 10 alluding to events at the "Copan" sky and cave/outcropping at Uxwitik.

3.2b Passage from Copan Stela 12 naming "Great Earth, the Edge of the Sky, the First Hearth Place cave/outcropping".

3.2c Passage from Copan Stela 2 naming "Great Earth".

3.2d Passage from the Main Panel of the Temple of the Cross, Palenque: "The hearth is changed at the Edge of the Sky, at the First Hearth Place".

3.2e Passage from Quirigua Stela C reading "It happened at the Edge of the Sky, at the First Hearth Place," in reference to the planting of a mythological stone.

3.2f Ik' wahynal mythological toponym from a Late Classic polychrome vessel.

3.2g Mythological toponyms ik' wahynal and ik' nabbnal from a Late Classic codex-style vessel.

3.3a Passage from Calakmul Stela 114 referring to a "youth, the Chiik Nahb lord".

3.3b Passage from Naranjo Hieroglyphic Stairway 1 (originally from Caracol) naming Yuknoom "Head" as "the Kaanal lord at Uxte'tuun, he of Chiik Nahb”.

3.3c “Chiik Nahb lord” on Calakmul Monument 6.

3.3d "Chiik Nahb wall” from the southern façade of Calakmul's North Acropolis.

3.3e Passage from an unprovenanced panel from the region of Cancuen. 
3.3f Passage from La Corona Panel 1A reading "Traveled to Chiik Nahb the elder brother person, the youth, K'ihnich Je' Yookil[?]”.

3.4a Early, innovative synharmonic spellings of the word for "cave, outcropping" at Copan: CH'EN-ne, from Copan Stela 12.

3.4b CH'EN-ne, from Copan Stela 2. Standard, disharmonic spellings of the same word.

3.4c CH'E'N-na, from Copan Stela 10, contemporaneous with Stelae 2 and 12.

3.4d CH'E’N-na, from Tikal Stela 5.

3.4e Standard spelling of the word for "image, person, self" as BAAH-hi, from the central panel of the Temple of the Inscriptions at Palenque.

$3.4 \mathrm{f}$ tu-BAAJ-ji for $t$-u baaj, "to his image," from Copan Stela E.

$3.4 \mathrm{~g}$ u-BAAJ-ji, "his image," from Copan Stela P.

4.1 Map of Egypt, showing sites mentioned in Chapter 4.

4.2 Northeastern corner of central court, upper terrace, Hatshepsut temple, Deir el-Bahri.

4.3 Butcher's Court looking southwest towards Room Z, Seti I temple, Abydos.

4.4 Architrave with Coptic religious texts, Butcher's Court, Seti I temple, Abydos.

4.5 Coptic-period niche in eastern wall of Tomb 29, Beni Hasan.

4.6 Coptic-period graffiti and holes, northeastern corner of Room Z, Seti I temple, Abydos.

4.7 Plastered installation in northeastern corner of Butcher's Court, Seti I temple, Abydos.

4.8 Daniel in the lion's den graffito on eastern wall of Tomb 23, Beni Hasan.

5.1 Map of the Amuq Plain showing the location of Tell Tayinat and other principal settlements.

5.2 Topographic map of Tell Tayinat overlaid on a CORONA satellite image of the site.

5.3 Plan of Building XVI, Tell Tayinat.

5.4 Plan of Building XVI, Tell Tayinat, showing the distribution of artifacts and tablets in its inner sanctum.

5.5 Plan of the Assyrian "Sacred Precinct" at Tell Tayinat, showing Buildings II and XVI.

6.1 Old Babylonian liver model allegedly from Sippar.

6.2 Old Babylonian omen compendium allegedly from Sippar.

6.3 Old Babylonian omen report allegedly from Sippar.

7.1 Scapula with divination records and scribal training exercises. 
7.2a Divination cracks, records, and exercises on HJ27456: divination cracks (obverse) and notches (reverse).

7.2b Divination cracks, records, and exercises on HJ27456: inscription units.

7.2c Divination cracks, records, and exercises on HJ27456: sequence of dated records and copies.

7.3 Divination records and trainee copies on HJ27456.

8.1 The scholarly knowledge network around seventh-century Kalhu.

8.2 The scholarly knowledge network around seventh-century Huzirina.

8.3 The scholarly knowledge network around fifth-century Uruk.

9.1 The epitaph of Philargyrus L. Sullae.

11.1 Aramaic incantation bowl, British Museum.

11.2 Incantation bowl for sale in Antiquities Shop, Jerusalem.

11.3 Incantation bowl for sale in Antiquities Shop, Jerusalem.

\section{List of Tables}

6.1 Provenience and number of omen compendia, early second millennium B.C.

6.2 Provenience and number of omen reports, early second millennium B.C.

6.3 Provenience and number of clay models, early second millennium B.C.

7.1 Known joins involving items from E.K. Smith's collection.

13.1 Sample questions posed to editors about their journals' publication policies.

13.2 Journals included in the survey and their editors. 


\section{Notes on Contributors}

Lisa Anderson (Ph.D., Brown University, 2009) is Frederick Randolph Grace Assistant Curator of Ancient Art in the Harvard Art Museums and former project manager of the U.S. Epigraphy Project, Brown University.

Neil J. Brodie (Ph.D., University of Liverpool, 1992) is Senior Research Fellow in the Scottish Centre for Crime and Justice Research at the University of Glasgow. Dr Brodie is an archaeologist by training and has held positions at the British School at Athens, the McDonald Institute for Archaeological Research at the University of Cambridge, where he was Research Director of the Illicit Antiquities Research Centre, and Stanford University's Archaeology Center. He was co-author (with Jennifer Doole and Peter Watson) of the report Stealing History (2000), commissioned by the Museums Association and ICOM-UK to advise upon the illicit trade in cultural material. He also co-edited (with Morag M. Kersel, Christina Luke, and Kathryn Walker Tubb) Archaeology, Cultural Heritage, and the Antiquities Trade (2006), (with Kathryn Walker Tubb) Illicit Antiquities: The Theft of Culture and the Extinction of Archaeology (2002), and (with Jennifer Doole and Colin Renfrew) Trade in Illicit Antiquities: The Destruction of the World's Archaeological Heritage (2001). He has worked on archaeological projects in the United Kingdom, Jordan, and Greece, where his work is ongoing.

Scott Bucking (Ph.D., University of Cambridge, 1998) is Associate Professor, Department of History, DePaul University. Professor Bucking's interests include the archaeology and epigraphy of late antique Egypt and Palestine, literacy and education in the ancient world, Greek and Coptic papyrology, and early Christianity and monasticism. His publications have appeared in the journals Public Archaeology, Palestine Excavation Quarterly, Zeitschrift für Papyrologie und Epigraphik, and Journal of Coptic Studies, and he is author of Practice Makes Perfect: P. Cotsen-Princeton 1 and the Training of Scribes in Byzantine Egypt (2011). He has two ongoing field projects: the Byzantine Cave Dwelling Project at Avdat, a UNESCO World Heritage Site in the Negev Desert of Israel, and the Beni Hasan in Late Antiquity Project in Middle Egypt, near Minya. He also currently serves on the Board of Trustees of the Albright Institute of Archaeological Research in Jerusalem. 
Nicholas P. Carter (Ph.D., Brown University, 2014) is Adjunct Lecturer, Department of Anthropology, Brown University. Since 2006 he has worked with the El Zotz Archaeological Project, which has been excavating at the ancient Maya site of El Zotz in central Petén, Guatemala, and directs the Sierra Mazateca Archaeological Project. His research interests include anthropological archaeology; the origins, nature, and disintegration of complex polities; linguistic and semiotic anthropology; writing systems; ancient economies; and ceramic analysis. He has worked on the noncalendrical component of the Zapotec hieroglyphic writing system, as well as the networks of cultural and political influence behind the palaeographic and linguistic trends in Classic Maya inscriptions.

John F. Cherry (Ph.D., Southampton University, 1981) is Joukowsky Family Professor of Archaeology and Professor of Classics, Brown University. His teaching, research interests, and publications are eclectic and reflect a background in Classics, Anthropology, and Archaeology, as well as educational training on both sides of the Atlantic, and archaeological fieldwork experience in Great Britain, the United States, Yugoslav Macedonia, Italy, Armenia, and (especially) Greece and (currently) Montserrat. He is co-author (with A. Bernard Knapp) of Provenience Studies and Bronze Age Cyprus: Production, Exchange and Politico-economic Change (1994), as well as co-editor (with Lauren E. Talalay and Despina Margomenou) of Prehistorians Round the Pond: Reflections on Aegean Prehistory as a Discipline (2005), (with Susan E. Alcock) Side-by-side Survey: Comparative Regional Studies in the Mediterranean World (2004), (with Susan E. Alcock and Jaś Elsner) Pausanias: Travel and Memory in Roman Greece (2001), and (with Colin Renfrew) Peer Polity Interaction and Socio-political Change (1986). He has been co-editor of the Journal of Mediterranean Archaeology for almost 25 years and is the General Series Editor for Joukowsky Institute Publications.

Patty Gerstenblith (Ph.D., Harvard University, 1977; J.D., Northwestern University School of Law, 1983) is Distinguished Research Professor of Law at DePaul University and director of its Center for Art, Museum and Cultural Heritage Law. She is founding President of the Lawyers' Committee for Cultural Heritage Preservation (2005-2011), a Director of the U.S. Committee of the Blue Shield, and Co-Chair of the American Bar Association's Art and Cultural Heritage Law Committee. In 2011 she was appointed by President Obama to serve as the Chair of the President's Cultural Property Advisory Committee in the U.S. Department of State, on which she had previously served as a public representative in the Clinton administration. From 1995 to 2002, she was editor-in-chief of the International Journal of Cultural Property. 
Her publications include the casebook Art, Cultural Heritage and the Law (2004; 3rd edition, 2012) and numerous articles. Before joining the DePaul faculty, Professor Gerstenblith clerked for the Honorable Richard D. Cudahy of the U.S. Court of Appeals for the Seventh Circuit.

Timothy P. Harrison (Ph.D., University of Chicago, 1995) is Chair of the Department of Near and Middle Eastern Civilizations, University of Toronto. Professor Harrison is the Director of the Tell Madaba Archaeological Project (Jordan) and the Tayinat Archaeological Project (Turkey) as well as a former President of the American Schools of Oriental Research (ASOR). He is the principal author of Megiddo 3: Final Report on the Stratum VI Excavations (2004), as well as numerous articles.

Morag M. Kersel (Ph.D., University of Cambridge, 2006) is Assistant Professor of Anthropology, DePaul University. Professor Kersel is CoDirector of two ongoing projects: Galilee Prehistory Project (Israel); "Follow the Pots" Project (Jordan). Her research interests include the Chalcolithic and Early Bronze Age of the eastern Mediterranean and Levant, cultural heritage protection, the built environment, object biographies, museums, and archaeological tourism. Her work combines archaeological, archival, and oral history research in order to understand the efficacy of cultural heritage law in protecting archaeological landscapes from looting. She is co-author (with Christina Luke) of U.S. Cultural Diplomacy and Archaeology: Soft Power, Hard Heritage (2013).

Eleanor Robson (D.Phil., Wolfson College, University of Oxford, 1995) is Reader in Ancient Near Eastern History in the Department of History, University College London. She was Co-Director (with Steve Tinney) of the Arts and Humanities Research Council-funded research project The Geography of Knowledge in Assyria and Babylonia (2007-2012) and is currently the British Institute for the Study of Iraq's voluntary Chair of Council. Dr Robson is the author or co-author of several books on Mesopotamian culture and the history of mathematics, most recently Mathematics in Ancient Iraq: A Social History (2008), which in 2011 won the History of Science Society's Pfizer Prize for the Best Scholarly Book. She co-edited (with Jacqueline Stedall) The Oxford Handbook of the History of Mathematics (2009) and (with Karen Radner) The Oxford Handbook of Cuneiform Culture (2011).

Christopher A. Rollston (Ph.D., The Johns Hopkins University, 1999) is Associate Professor of Northwest Semitic Languages and Literatures in the Department of Classical and Near Eastern Languages and Civilizations, 
The George Washington University. Professor Rollston is the editor of the journal MAARAV: A Journal for the Study of Northwest Semitic Languages and Literatures and co-editor (with Eric Cline) of the Bulletin of the American Schools of Oriental Research. He was educated as a critical historian and a philologist of ancient Near Eastern languages, with Northwest Semitic epigraphy, ancient scribal education, literacy in the ancient Levant, Hebrew Bible, and Second Temple Jewish Literature as his strongest emphases. He works in more than a dozen ancient and modern languages, especially the biblical languages (Hebrew, Aramaic, and Greek), as well as Akkadian, Ugaritic, Phoenician, Ammonite, Moabite, and Sahidic Coptic. He has published widely in the area of Northwest Semitic epigraphy and is author of Writing and Literacy in the World of Ancient Israel: Epigraphic Evidence from the Iron Age (2010), which received the Frank Moore Cross Epigraphy Prize of the American Schools of Oriental Research.

Matthew T. Rutz (Ph.D., University of Pennsylvania, 2008) is Assistant Professor in the Department of Egyptology and Assyriology, Brown University. Professor Rutz works in the field of Assyriology with emphasis on Akkadian (Babylonian/Assyrian) and Sumerian documents from the late second and first millennia B.C., the social and political history of the Late Bronze Age, Babylonian literary and scholastic texts from the site of Nippur (Iraq), divination and medicine in ancient Mesopotamia, the textual transmission of cuneiform literature, and the study of ancient texts as archaeological objects. $\mathrm{He}$ is the author of Bodies of Knowledge in Ancient Mesopotamia: The Diviners of Late Bronze Age Emar and Their Tablet Collection (2013).

Adam Smith (Ph.D., University of California, Los Angeles, 2008) is Assistant Professor in the Department of East Asian Languages and Civilizations, University of Pennsylvania, where he is also Assistant Curator in the University of Pennsylvania Museum of Archaeology and Anthropology's Asian Section. Professor Smith's ongoing research focuses on the emergence and evolution of the Chinese writing system during the late second and first millennia B.C., and the early literate activities with which it was associated. $\mathrm{He}$ is currently working on a monograph on the topic of divination and its written record in early China.

Matthew W. Stolper (Ph.D., University of Michigan, 1974) is Emeritus Professor of Assyriology and John A. Wilson Professor Emeritus of Oriental Studies in the Oriental Institute and the Department of Near Eastern Languages and Civilizations of the University of Chicago. Professor Stolper has worked on Achaemenid Babylonian history and texts as well as on Elamite 
history and texts. As Director of the Persepolis Fortification Archive Project, his efforts are focused on Achaemenid administrative records excavated by the Oriental Institute in 1933 at Persepolis, the imperial residence in the Persian homeland, to be published in electronic and conventional forms. He is author of Tall-i Malyan, I: Elamite Administrative Texts (1972-1974) (1984), (with Elizabeth Carter) Elam: Surveys of Political History and Archaeology (1984), Entrepreneurs and Empire: The Murašû Archive, the Murašû Firm, and Persian Rule in Babylonia (1985), Late Achaemenid, Early Macedonian and Early Seleucid Records of Deposit and Related Texts (1993), and (with Veysel Donbaz) Istanbul Murašû Texts (1997), as well as numerous articles.

Heidi Wendt (Ph.D., Brown University, 2013) is Assistant Professor in the Departments of Religion, Philosophy, and Classics, Wright State University. Her interdisciplinary research focuses on religion in the Roman Empire, including early Christianity, and the activities of freelance religious experts and their significance for the emergence of Christians in the first century. Professor Wendt is interested in relationships between Roman and provincial religions, particularly in Roman strategies for negotiating the "foreign" ritual practices and spaces with which they came into contact through imperial expansion. In 2011 she was awarded the Emeline Hill Richardson PreDoctoral Rome Prize in Ancient Studies from the American Academy in Rome. She has worked on archaeological projects and conducted research throughout Italy, Greece, and Turkey. 


\section{Contributor Addresses}

\section{Lisa Anderson}

Division of Asian and Mediterranean Art

Harvard Art Museums

32 Quincy St

Cambridge, MA 02138

lisa_anderson@harvard.edu

Neil J. Brodie

Scottish Centre for Crime and Justice Research

University of Glasgow

Ivy Lodge, 63 Gibson St

Glasgow G12 8LR

Scotland

Neil.Brodie@glasgow.ac.uk

\section{Scott Bucking}

Department of History

DePaul University

2320 N. Kenmore Ave

Chicago, IL 60614

sbucking@depaul.edu

Nicholas P. Carter

Department of Anthropology

Brown University, Box 1921

Providence, RI 02912

Nicholas_P_Carter@brown.edu

John F. Cherry

Joukowsky Institute for Archaeology

and the Ancient World

Brown University, Box 1837

60 George St

Providence, RI 02912

John_Cherry@brown.edu
Patty Gerstenblith

DePaul University College of Law

25 E. Jackson Blvd

Chicago, IL 60604

pgersten@depaul.edu

Timothy P. Harrison

Department of Near and Middle Eastern Civilizations

University of Toronto

4 Bancroft Ave

Toronto, ON

Canada M5S 1C1

tim.harrison@utoronto.ca

Morag M. Kersel

Department of Anthropology

DePaul University

2343 North Racine Ave

Chicago, IL 60614

mkersel@depaul.edu

Eleanor Robson

Department of History

University College London

Gower St

London WC1E 6BT

United Kingdom

e.robson@ucl.ac.uk

Christopher A. Rollston

Department of Classical and Near Eastern Languages and Civilizations

The George Washington University 801 22nd St NW, Phillips Hall 345

Washington, DC 20052

rollston@gwu.edu 
Matthew T. Rutz

Department of Egyptology and Assyriology

Brown University, Box 1899

2 Prospect St

Providence, RI 02912

Matthew_Rutz@brown.edu

\section{Adam Smith}

University of Pennsylvania Museum of Archaeology and Anthropology 3260 South St, Room 510

Philadelphia, PA 19104

adsmit@sas.upenn.edu
Matthew W. Stolper

Oriental Institute

University of Chicago

1155 E 58th St

Chicago, IL 60637

m-stolper@uchicago.edu

\section{Heidi Wendt}

Religion, Philosophy, and Classics

Wright State University

Millett Hall 370

3640 Colonel Glenn Hwy

Dayton, OH 45435

heidi.wendt@wright.edu 


\section{Acknowledgments}

This volume grew out of a symposium hosted at Brown University on December 3-5, 2010, the purpose of which was to explore different perspectives on the interplay of archaeological and textual material from the ancient world - hence archaeologies of text. For the symposium we invited scholars who routinely engage with the archaeology of texts - archaeologists, classicists, epigraphers, papyrologists, philologists, Assyriologists, Egyptologists, Mayanists, ancient historians - to discuss current theoretical and practical problems that have grown out of their work on early inscriptions and archaeology, and we warmly thank all contributors and participants for their interest, energy, and thoughtful engagement with this perennially relevant, promising, and vexing topic. Our hope was that the variety and specificity of perspectives and methods under discussion would catalyze cross-disciplinary exchange as well as underscore the importance of reevaluating the wellestablished disciplinary practices and assumptions within our respective fields. We leave it to the reader to decide if we succeeded in our approach, even if only asymptotically.

The symposium was generously supported by several institutional sponsors that we are only too happy to thank: the Department of Egyptology and Assyriology (James P. Allen, then Chair), the Joukowsky Institute for Archaeology and the Ancient World (Susan E. Alcock, Director), the Program in Early Cultures, and The Colver Lectureship Fund at Brown University, and the Department of Anthropology at DePaul University. Additional funding for publishing this volume was provided by the Joukowsky Institute for Archaeology and the Ancient World and the Humanities Research Fund of Brown University's Office of the Vice President for Research.

Institutional support is essential, but it is people who give vitality and meaning to symposia such as ours. Over and above the authors of the individual chapters included herein and the many people who came to Brown to participate in the symposium, we gladly acknowledge a number of others by name. Bruce Zuckerman of the University of Southern California gave a stimulating presentation at the symposium, but due to personal reasons he was unable to contribute a chapter to this book. Sue Alcock and Jim Allen were pivotal in making the symposium a success. Claire Benson, 
Diana Richardson, and Sarah Sharpe provided enthusiastic and capable administrative and logistical support. Doctoral students from a number of programs at Brown University served as session chairs: Bryan Brinkman, Kathryn Howley, Jessica Nowlin, Timothy Sandiford, Julia Troche, and Zackary Wainer. Subsequently a number of Brown graduate students (some of whom were also chairs) took a graduate seminar that grew out of the symposium: Emanuela Bocancea, Müge Durusu-Tanriöver, Katherine Harrington, Ian Randall, Timothy Sandiford, and Alexander Smith (Archaeology and the Ancient World); Scott DiGiulio and Christopher Geggie (Classics); Christian Casey, Kathryn Howley, and Julia Troche (Egyptology); M. Willis Monroe and Zackary Wainer (Assyriology). Clive Vella, Ian Randall, and Magdelyne Christakis assisted with editing some of the individual chapters. John Cherry must also be singled out for a final word of thanks. He was a supporter of this enterprise from its inception and later took on a number of roles: as participant in the symposium, as thoughtful contributor to the volume, and as attentive series editor. 


\title{
Tracing Networks of Cuneiform Scholarship with Oracc, GKAB, and Google Earth
}

\author{
ELEANOR RoBSON
}

\section{Oracc: Facilitating the Online Dissemination of Cuneiform Text}

Since the cuneiform script began to be deciphered in the mid-nineteenth century, it has by and large remained the preserve of a small group of specialists. A few writings from the ancient Middle East have penetrated popular consciousness - the Laws of Hammurabi, the Epic of Gilgamesh, and perhaps the Babylonian Epic of Creation - and, particularly since James B. Pritchard's pioneering Ancient Near Eastern Texts Relating to the Old Testament (1st edn. 1950 and still in print today), print anthologies have disseminated larger bodies of translations to academic, educational, and wider readerships, especially through series such as Writings from the Ancient World, The Context of Scripture, and State Archives of Assyria in English, Texte aus der Umwelt des Alten Testaments in German, and Littératures anciennes du Proche-Orient in French, as well as in a number of stand-alone works (e.g., recently, Black et al. 2004; Chavalas 2006; Foster 2005). But anthologies are necessarily selective, subject as they are to the constraints and conventions of the commercially viable book, which makes them relatively intractable as research resources for those without access to, or expertise in, the original sources.

Since the mid-1990s there have been various attempts to create online corpora of cuneiform texts, but even the most long-lived and successful - namely the Cuneiform Digital Library Initiative (CDLI, cdli.ucla.edu) and The Electronic Text Corpus of Sumerian Literature (ETCSL, etcsl.orinst. ox.ac.uk) - have their drawbacks as well as their strengths. By the end of 2010 CDLI contained records of some 250,000 cuneiform tablets, but its primary focus is providing basic reference transliterations of inscribed objects, rather than offering a scholarly working environment for the 
development of analytic tools or easy comprehensibility for non-expert users. The ETCSL project (1996-2006), by contrast, produced text editions of some 400 works of Sumerian literature from the period 2100-1600 B.C., in alphabetic transliteration and English translation, with sophisticated textual search and linguistic analysis tools. There, though, the emphasis was on the reconstruction of whole compositions rather than the documentation of individual manuscript witnesses. Both projects have been addressed primarily to cuneiformists rather than to a wider public.

Over the past few years, a new consortium of online projects has grown up, steered by a small group of us, who had been (and still are) closely involved with CDLI and ETCSL in various ways and wished to retain or develop the best practices of both projects, while offering new facilities for the widest possible range of users, in order to complement CDLI's central archival role as a catalogue, image database, and transliteration repository. Oracc - The Open, Richly Annotated Cuneiform Corpus (oracc.org) - went public in mid-2010. Developed by Steve Tinney and steered by him, Niek Veldhuis, and myself, it comprises a workspace and toolkit for the development of a complete corpus of cuneiform whose rich annotation and open licensing are designed to support the next generation of scholarly research and online dissemination of data and findings. Let us look at each of those features in turn.

Oracc is open in several senses. ${ }^{1}$ Most obviously, the data and tools it provides are released under a Creative Commons Attribution Share-Alike license (http://creativecommons.org/licenses/by-sa/3.0/), meaning that all users and developers are free to access, create, and re-use Oracc material without formal permission, as long as they attribute the original work to its creator(s) and funders, and release their derived work under a similarly open licensing agreement. Just as fundamentally, the Oracc Steering Committee is committed to principles of co-operative, collaborative, responsive working. Our goal is to provide standards-based, well-documented resources that are as simple, flexible, and adaptable to user needs as possible, and supported by free server space, backup, and personal contact with Oracc liaison staff (for more information, see http://oracc.org/doc/about/aboutoracc/index.html).

Oracc aims to encourage the development of a comprehensive cuneiform corpus, as inclusive and exhaustive as possible, across languages (Sumerian, Akkadian, Hittite, Elamite, Aramaic, Old Persian, etc.), script type, time (ca. 3300 B.C.-A.D. 100), place (across the Middle East from Anatolia to Egypt to Iran), and genre (from mundane administrative records to arcane scholarly works). It does so by facilitating individual corpus-based projects across the world, each with their own aims, objectives, and funding. By the end of 2010 it comprised seven major public corpora, plus a further 15 in 
development. While some, such as The Digital Corpus of Cuneiform Lexical Texts (DCCLT, oracc.org/dcclt), track particular genres through time, others, such as The State Archives of Assyria online (SAAo, oracc.org/saao), provide access to multiple genres of texts from particular times or places. Some, such as SAAo, are re-presentations and developments of print publications; others, such as DCCLT, are born digital. Further projects, currently under development, will be released online and in print simultaneously. Minimally, projects consist of alphabetic transliterations of cuneiform text corpora, with associated catalogue metadata (which may be drawn from CDLI), but Oracc also encourages the provision of translations, in any modern language - or more than one - as well as various types of annotation.

Oracc corpora can be richly annotated in several senses. Oracc provides various tools for the linguistic annotation of cuneiform texts, from lemmatisation (the association of individual spellings of words to dictionary head-words for the generation of language glossaries), to the analysis of number systems (in economic, mathematical, or astronomical contexts, for instance), orthography (spelling habits), prosopography (patterns of naming), and social networks (who trades or trains or communicates with whom). We are also in the process of developing a range of infrastructure projects, currently planned to include super-glossaries of Sumerian and Akkadian, and a global sign list of cuneiform. Finally, we also offer facilities for creating portal websites which serve as the introductory front-end to individual projects. These sites - such as the SAAo portals Assyrian Empire Builders (www.ucl.ac.uk/sargon) and Knowledge and Power in the Neo-Assyrian Empire (K\&P, oracc.org/saao/knpp) - enable projects to present explanatory or supplementary material to non-specialist audiences, whether background essays, glossaries of technical terms, summaries of the project's aims and findings, or any other content.

We provide all Oracc corpora and Oracc-hosted portal sites with visitor access statistics so that project directors can report to their funders or institutions on the range and depth of their online outreach. For instance, in January 2011 SAAo had some 370 unique visitors from 32 countries, making nearly 1,300 visits between them and accessing an average of 20 pages each. During the same month one of its portals, K\&P, had nearly 3,300 visitors from 105 different countries, who made a total of 4,500 visits and accessed around 3 pages each time. Given that 370 would be a generous estimate of the number of professional cuneiformists worldwide, and 3,300 a similarly generous estimate of the number of their graduate students, it is clear that Oracc corpora and associated portal sites are enabling cuneiform texts to reach a more global - and educationally diverse - audience than ever before. ${ }^{2}$ 


\section{GKAB: Researching the Ancient Dissemination of Cuneiform Scholarship}

One of Oracc's core projects is The Geography of Knowledge in Assyria and Babylonia, 700-200 B.C. (GKAB, oracc.org/cams/gkab), funded by the U.K. Arts and Humanities Research Council (2007-2012), and jointly directed by Tinney and myself at the Universities of Pennsylvania and Cambridge. Its core aim was to investigate the generation, replication, dissemination, and consumption of scholarly knowledge in cuneiform culture. Questions about the ownership and accessibility of knowledge, the circumstances and environments in which it flourishes or perishes, the socio-political influences and impacts of its transmission and reception, are all central to the history and sociology of science. GKAB addressed these ideas in relation to ancient Assyria and Babylonia in the first millennium B.C., while exploring the potential and limitations of applying and adapting methodologies designed to analyse modern techno-science for the study of ancient scholarship (Robson 2011). GKAB's central dataset comprises online editions of nearly 1,500 scholarly manuscripts, a major component of the Oracc-hosted Corpus of Ancient Mesopotamian Scholarship (CAMS, oracc.org/cams). Learned writings are probably (almost) as old as cuneiform script itself (Veldhuis 2006), but GKAB focused on the tablets found in and around just four discrete buildings from a 500-year period of the first millennium B.C., all formally excavated and at least minimally published, but none hitherto subjected to holistic study and analysis. Such collections are commonly called "libraries" in Assyriological parlance (e.g., Clancier 2009; Pedersén 1998). I have addressed the thorny question of what constitutes a cuneiform library elsewhere (Robson 2013; Robson and Stevens in press); here I shall simply avoid the term wherever possible.

From the ninth to seventh centuries B.C., Assyria was by far the most powerful empire of the Mediterranean and Middle East. The ideology of empire centred on the symbiotic relationship between the king and the great god Aššur: military conquest was both an act of devotion and confirmation of Aššru's support. But Assyrian kingship depended not solely on piety and military might. A retinue of scholarly advisors guided royal decision-making through the observation and analysis of omens, and the performance of appropriate rituals (Radner 2011). The scholars in turn depended on a wide range of scholarly works written on cuneiform tablets, from astronomy to mythology, kept both in private households and in institutions such as temples and palaces. Two of the GKAB corpora stem from seventh-century Assyria, one belonging to a temple in the royal city of Kalhu, close to the capital Nineveh, and the other deliberately hidden outside a private house in the western provincial town of Huzirina several hundred miles away. 
After Assyria fell in 612 B.C., Babylonian scholarly activity continued to flourish and develop under the patronage of wealthy urban temples in the south. Here scholarship was adapted to new purposes of maintaining the intellectual integrity and social status of native religion in the face of new ways of thinking and believing. The courts of Achaemenid (ca. 540-330 B.C.) and Seleucid (ca. 330-130 B.C.) rulers no longer supported cuneiform scholarly traditions. New genres came into being; others were adapted or survived relatively unchanged; still others disappeared completely. Temples were the last bastions of cuneiform scholarship until at least the final centuries B.C. The GKAB project focused on three assemblages of scholarly tablets from the southern city of Uruk. Two are from successive strata of a well-todo house in the southeastern corner of the city, occupied consecutively by two apparently unrelated families of mašmašsus ("incantation priests") in the late-fifth and late-fourth centuries B.C. The third, which I shall not discuss further here, has been reconstructed from tablets excavated from a secondcentury storeroom in one of the city's central temples, together with tablets stemming from illicit diggings in the vicinity in the early twentieth century (on the tablets from this temple, see Robson 2013).

By looking at similarity and difference across the five groups of tablets, and by drawing on appropriate comparanda from other places and periods, the GKAB project addressed some fundamental questions about the changing meanings and functions of literate scholarship in first-millennium cuneiform culture. Of particular relevance to the geography of knowledge are questions concerning the relationship(s) between scholarly practice, familial inheritance, and royal power, as well as the survival, adaptation, and development of learning in face of political change.

These are novel topics for Assyriological study. Since A. Leo Oppenheim's articulation of the notion of a "stream of tradition" (Oppenheim 1960), it has been commonplace to posit a stable corpus of scholarly writings which was relatively accessible to all learned men, through copying and commentary, as part of their formal education throughout the first millennium B.C. At midcentury this was a reasonable inference from the evidence then available, which was weighted heavily to the famous and gargantuan "Library of Assurbanipal" from seventh-century Nineveh in the absence of the large number of smaller, formally excavated assemblages that have since become available. This is not the place for a longer discussion of the relevant historiography and excavation/publication history of the material (Robson 2011) or an up-todate survey of excavated assemblages of cuneiform scholarship from the first millennium B.C. (Robson and Stevens in press). However, it is now clear that this apparently archetypal "Library of Assurbanipal" is in fact atypical in several key ways (Robson 2013). First, containing tens of thousands of 
manuscripts, it was about 50 times the size of any other scholarly tablet collection now known. For example, the so-called äšipus' house in seventhcentury Assur and the Ebabbar temple in sixth-century Sippar each held a collection of about 800 tablets (Pedersén 1998: 135-136, 194-197). Second, it was assembled, at least in part, through coercion and conquest, while most scholarly communities - without world-class armies at their disposal - had to rely on the more normal means of inheritance, collection, and copying. Third, at its apogee, it was directly shaped by the close involvement of two of the most powerful men in the ancient world: the Assyrian king Esarhaddon (r. 681-669 B.C.) and his son Assurbanipal (r. 669-ca. 630 B.C.).

Further, it is only since Oppenheim's day that the mechanisms and motivations behind the dissemination of knowledge have been the subject of sustained academic study. Most relevant for our purposes here is the work of the sociologist of science Bruno Latour, who articulated several related concepts that have opened up new lines of geographical research:

If techno-science may be described as being so powerful and yet so small, so concentrated and yet dilute, it means it has the characteristics of a network. The word network indicates that resources are concentrated in a few places - the knots and the nodes - which are connected with one another - the links and the mesh: these connections transform the scattered resources into a net that may seem to extend everywhere [Latour 1987: 180; emphasis added].

If we in turn understand the scholars of cuneiform culture as actors in a Latourian network, it becomes apparent why earlier generations of Assyriologists perceived the intellectual world those scholars created as ubiquitous, monolithic, and self-sustaining.

But for Latour, people are not the only actors in the network; objects are too, and in particular inscriptions (whether computer printouts or cuneiform tablets) are "immutable and combinable mobiles ... conveniently at hand and combinable at will, no matter whether they are twenty centuries old or a day old" (Latour 1987: 227; emphasis added). In other words, writing travels as much as people do, taking established knowledge to new places, and enabling new knowledge to be created through acts of editing and rewriting. In order for this to happen the messy observables of the real world have to be reduced and simplified into manageable scientific (or scholarly) data: "Metrology is the name of this gigantic exercise to make of the outside a world inside which facts and machines can survive" (Latour 1987: 251; emphasis added). The final act in the transformation of new knowledge into established truth is to "black box" it, or erase all traces of the process of production: "The word black box is used by cyberneticians whenever a piece of machinery or a set of commands is too complex. In its place they draw a little box about 
which they need to know nothing but its input and output" (Latour 1987: 2). According to the Oxford English Dictionary Online, the term "black box" was originally Royal Air Force slang for "a navigational instrument in an aircraft," later extended to denote any "device which performs intricate functions but whose internal mechanism may not readily be inspected or understood" (OED Online 2013). Cuneiform scholars, we can now see, were masters of black-boxing: almost no evidence remains of how their learned writings came to be.

By taking a Latourian view of the production and dissemination of scientific knowledge, and by plotting the origins of people, writings, and deities on Google Earth, we are able to see afresh the means and routes by which scholarship travelled around the buildings and communities studied by the GKAB project. Here I focus on just three of them, which - as we shall see - are sufficient to challenge the old assumption that all cuneiform "libraries" served essentially the same functions for essentially the same sorts of people.

\section{Kalhu: An Assyrian Royal City}

The city of Kalhu on the Tigris (biblical Calah, modern Nimrud) was the Assyrian imperial capital for much of the ninth and eighth centuries, and continued to function as a royal city until its fall in 614 B.C. (on the archaeology of Kalhu, see Curtis et al. 2008; Mallowan 1966; Oates and Oates 2001). A short walk from the palace was a temple named Ezida, dedicated to the god of wisdom Nabu. Fully half of the 250-odd scholarly tablets found in a room immediately opposite his shrine bear omens, incantations, and rituals - for advising the Assyrian king on political decision-making and for helping him to maintain his relationship with the gods. A further quarter comprise hymns and lexical works (standardised lists of words and cuneiform signs), while the majority of the remainder comprise medical, literary and calendrical writings (on the scholarly tablets from Kalhu, see Black 2008; Pedersén 1998: 151-152; Wiseman and Black 1996; and http://oracc.org/ cams/gkab/kalhu). The generic profile of the collection is very similar to that of the libraries at Nineveh (Robson 2013).

Some 30 scholarly tablets of the Kalhu Ezida corpus have extant or partially surviving colophons, from which at least 15 names of scholars can be identified. Many of them belong to just two dynasties of Assyrian royal scholars. The earliest comprises several generations of the descendants of Ištaran-šumu-ukin, a tenth(?)-century āšip šarri ("royal exorcist"):

- Ištaran-mudammiq, šaggamab̧hu ("senior exorcist") of king Assurnaṣirpal II (r. 883-859 B.C.), son of Tappuya, šatammu ("temple administrator") of Der 
and grandson of the satammu Huzalu; owner of an ominous calendar for the month of Tašritu (CTN 4, 58; duplicate KAR 147, with the same colophon, found in Assur);

- Ištaran-mudammiq's grandson (name missing), son of Nabu-mudammiq; owner or copyist of a compendium of incantations called Utukkü lemnütu "Evil demons" (CTN 4, 103); possibly Babilaya (see below) or a brother of his;

- Ištaran-mudammiq's great-grandson Marduk-[...], the tupšar šarri ("royal scribe"), and ummânu ("scholar") of king Adad-nerari III (r. 811-783 B.C.); son of the äšip šarri Babilaya; owner of a tablet of celestial omen series Enüma Anu Ellil (CTN 4, 8, dated 787 B.C.).

By the late eighth century, it appears that the Ištaran-šumu-ukin family had been ousted or superseded by the descendants of Gabbu-ilani-ereš, ummânu of Assurnașirpal II (and thus Ištaran-mudammiq's contemporary):

- Adad-šumu-ușur, chief ãšipu of king Esarhaddon and son of the famous scholar Nabu-zuqup-kena; owner of a tablet from the terrestrial omen series Šumma àlu (CTN 4, 45);

- a son (name missing but possibly Šumaya) of his brother Nabu-zeru-lešir (?), Esarhaddon's chief scribe; copyist of an ominous calendar (CTN 4, 59) "for the prolongation of his life;" ${ }^{3}$

- further sons or descendants of Nabu-zuqup-kena are mentioned in colophons of two tablets of physiognomic omens Alandimm $\hat{u}$ and another of unidentified omens (CTN 4, 74; 78; 89).

- Nabu-le'i, son of Adad-šumu-ușur's close associate, Esarhaddon's chief lamenter Urad-Ea; scribe of a hitherto unidentified ritual (CTN 4, 187), which he "copied like its original for him to see".

Nabu-zuqup-kena himself, chief scribe to kings Sargon II (r. 721-705 B.C.) and Sennacherib (r. 704-681 B.C.), wrote over 60 surviving scholarly tablets, nearly two-thirds of which explicitly state that they were written in Kalhu (Hunger 1968: 90-95, nos. 293-311, of which nos. 293-294 and 305 name Kalhu). However, the tablets themselves belong to the Kuyunjik collection of the British Museum, most likely meaning that they were excavated by Layard and his associates from the royal citadel of Nineveh. Likewise, his sons Adad-šumu-ușur and Nabu-zeru-lešir are well attested in Assyrian court correspondence from Nineveh, sometimes in collaboration with Urad-Ea and other colleagues. ${ }^{4}$ Adad-šumu-ușur also worked at Kalhu, where he is documented performing a ritual against two types of fungi that had infested Ezida (SAA 13, 71). Coincidentally or not, a tiny fragment of Šumma älu ("If a city") Tablet XIII, containing omens about fungus growths, is amongst the extant scholarly tablets from the Kalhu Ezida (CTN 4, 36).

By contrast, the only other well-documented scholar in the temple conspicuously never mentions his family: ${ }^{5}$ 
- Banunu, an àšipu, is copyist and/or owner of four scholarly tablets: a prayer of divination "from a Babylonian original" (CTN 4, 61); the ritual Mis $p \hat{\imath}$ "Mouth opening" (CTN 4, 188); medical recipes (CTN 4, 188); and the medical plant list Uruanna (CTN 4, 192). In the colophons of the second and third he exhorts, "Do not disperse the gerginakku (library); taboo of Ea, king of the Apsu". The copyist of a cultic commentary (CTN 4, 185), whose name is now missing, also asks for that tablet [not to be removed] "from the gerginakku (library) of the temple."

It is possible, but by no means certain, that this is the same Banunu who, in the aftermath of Assurbanipal's conquest of Babylonia, was assigned oversight of the governor of Nippur's son in the Succession Palace at Nineveh after he had finished copying out Enüma Anu Ellil ("the Series") (SAA 11, 156; Parpola 1983).

The Ezida at Kalhu was not the only Assyrian royal temple to Nabu, god of wisdom. In 717 B.C. Sargon began construction work on a new capital city, Dur-Šarruken (modern Khorsabad), some 30 miles upriver of Kalhu. Within the citadel, adjacent to the palace and linked to it by a private walkway, he commissioned a bigger and better Ezida. This new temple was furnished with two rooms fitted with pigeonholes for storing tablets, one in the outer courtyard and one in the courtyard closest to Nabu and Tašmetu's shrines (Loud and Altman 1938: 56-64, pls. 2, 12-29). Sargon endowed the temple with 4,000 homers of land, regular offerings of sheep, and daily provisions of bread and beer for an àšipu and labbinu ("temple steward") (SAA 1: 88, no. 106, and 102-105, nos. 128-129). At least one set of new writing boards was commissioned, containing the celestial omen series Enüma Anu Ellil (Wiseman 1955), and further library holdings may also have been moved there from Kalhu.

Dur-Šarruken was functional and occupied by 707 B.C. but abandoned just two years later, following Sargon's inauspicious death in battle. His son and successor Sennacherib moved the court to Nineveh, an ancient Assyrian city between Dur-Šarruken and Kalhu, where a temple of Nabu had been founded by Adad-nerari III in 788 B.C. and restored by many successive kings (Reade 1998-2001: 410). Almost nothing of it now survives except the $60 \mathrm{~m}$-square foundation platform. However, a number of scholarly tablets in the Kuyunjik Collection of the British Museum bear colophons dedicated by Assurbanipal to the gerginakku ("library") of the Ezida "that is in the middle of Nineveh" (Hunger 1968: 101-102, nos. 327-328, 105-107, nos. 338-339), so it is clear that it had a significant scholarly function. Presumably the holdings of the abandoned Dur-Šarruken Ezida were moved here, or back to Kalhu, or both, for Kalhu remained a royal city - and its Ezida remained active - until the very end of empire. For instance, one Nabu-sakip made 


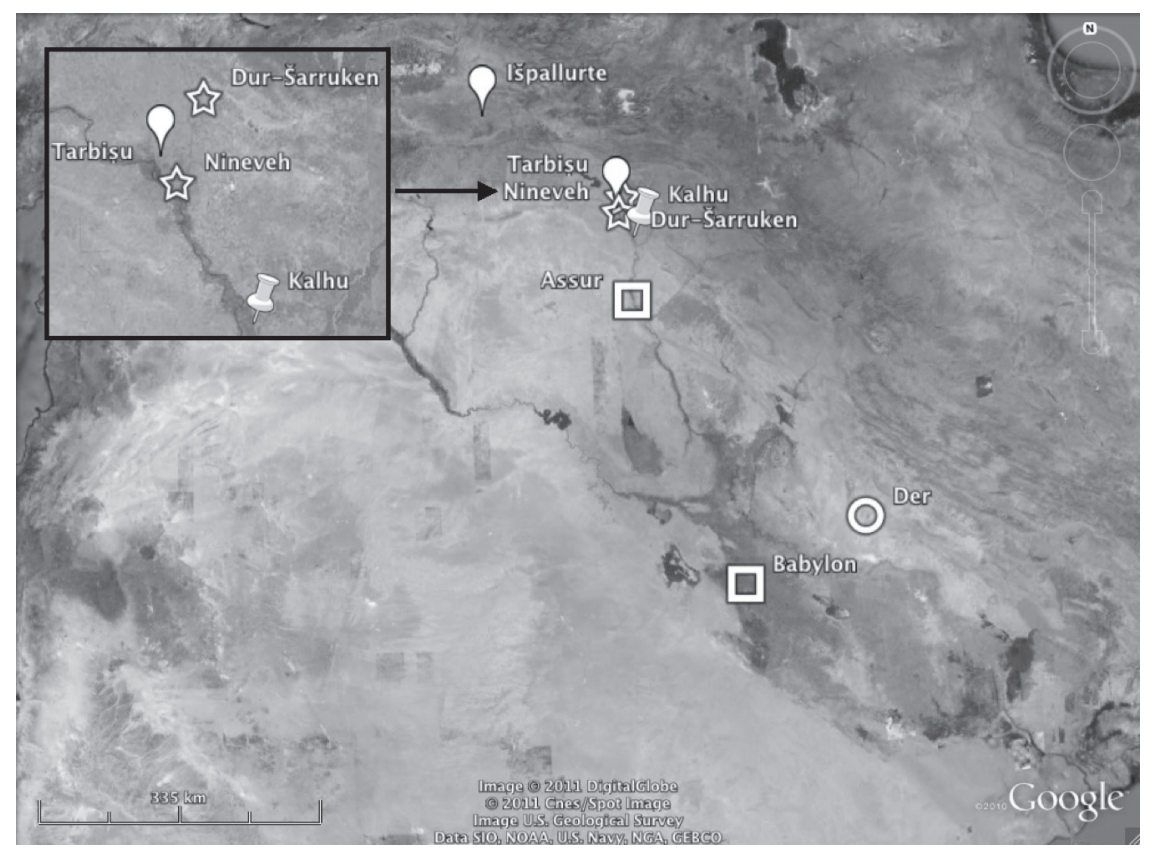

Figure 8.1. The scholarly knowledge network around seventh-century Kalhu. Key: 回 = origins of tablet originals or duplicates; () = origins of ancestors; $=$ locations of other Ezida temples in the network; $\nabla=$ locations of activities of Kalhubased scholars.

a private benefaction of two slaves and seven homers of land to the Kalhu Ezida in 621 B.C. (SAA 12, 96), just seven years before it fell to the Medes and Babylonians.

In sum, the scholars of the Kalhu Ezida were - perhaps unsurprisingly - deeply embedded in a tightly-knit Assyrian royal knowledge network (Figure 8.1). For the most part descended from eminent scholarly dynasties, they were so closely tied to their divine and royal patrons that they and their writings, indeed their very institution, moved as the court relocated following political imperatives. Coincidentally or not, it was only Banunu, with no family to speak of, who copied a text "from a Babylonian original" - the sole extant acknowledgement of scholarship beyond the Assyrian court.

\section{Huzirina: A Provincial Town in the Assyrian West}

The nearly 400 tablets found buried outside a domestic dwelling in the provincial Assyrian town of Huzirina (modern Sultantepe), near Harran, 
comprise a striking contrast to those found in contemporary royal cities such as Kalhu (on the archaeology of Huzirina, see Lloyd 1954; Lloyd and Göçke 1953). As well as hymns, incantations, and rituals, there is a preponderance of literary works in the assemblage, but very few omen collections (on the tablets, see Gurney 1952; Gurney and Finkelstein 1957; Gurney and Hulin 1964; Pedersén 1998: 178-180; http://oracc.org/cams/ gkab/huzirina). Compared to the Kalhu tablets, the Huzirina manuscripts tend to be very poorly executed (Gurney 1952: 26). Nearly 60 of them have surviving colophons, together attesting to the activities of around 25 different scribes (Hunger 1968: 110-120, nos. 351-408). As in Kalhu, they can be differentiated into two distinct groups. The first is a priestly family, descended from one Nur-Šamaš (Gurney 1997), and their associates:

- Qurdi-Nergal, šangĥu-priest of the gods Zababa and Bau of Arbela, Harran, and Huzirina; a šamallû agašg $\hat{u}$ ("novice apprentice") in 701 B.C., when he wrote a bilingual listing of the incantation series Utukkü lemnütu (STT 2, 192);

- his son Mušallim-Bau, a šamallûu (agašgû), who copied various incantations and rituals, an ominous calendar, and a medical text (STT 2, 179; 199; 299; 305 and maybe STT 1, 64);

- his descendant Ninurta-[..], a šamallû șehru (“junior apprentice”), son of the šamallû șehru Nabu-zer-kitti-lešir, who copied a calendar for incantations (STT 2, 300) in 619 B.C.;

- the samallù ("apprentice") and eunuch Nabu-ah-iddin, copyist of four incantations and rituals (STT 2, 161; 172; 237; 247) who sometimes writes ana tämarti ("for the viewing of") Qurdi-Nergal;

- Nabu-ah-iddin’s mär mummu ("pupil”), the šamallû șeb̧ru Nabu-rehtu-ușur, who copied the literary work The Poor Man of Nippur (STT 1,38) in 701 B.C. ana tämarti ("for the viewing of") Qurdi-Nergal, writing: "Do not disperse the library (gerginakku); taboo of Ea, king of the Apsu," just like Banunu of Kalhu.

Apart from Qurdi-Nergal's family and immediate associates, tablets from the Huzirina cache record over 20 further writers, including:

- Adad-mušammer, a šamallù šubultinbi ("young apprentice"), son of the scribe Nergal-tukulti; copyist of the literary Gilgamesh Letter (STT 1, 40);

- Bel-le'u-ușur, a šamallî̀ šubultinbi, son of Marduk-ban-apli, scribe of the turtannu ("field marshal"), who copied out a now unidentifiable text (STT $2,342)$

- Iddi-Meslamtaea, a šamallû, son of the šangĥu-priest Ašu, copyist of three manuscripts of Utukkü lemnütu (STT 2, 159; 174; 177), a god list (STT 2, 377), and Tablet 2 of the literary work Ludlul bèl nèmeqi "Let me praise the lord of wisdom" (STT 1, 33) in and around 701 B.C.; 
- Mutaqqin-Aššur, a šamallûu daqqu ("tiny apprentice”), son of a scribe from Assur, grandson of the šamallû̀ šubultinbi Šamaš-šum-iddina, and greatgrandson of Nabu-kabit-ahhešu, a scribe from the Babylonian city of Kutha; copyist of a blessing for the city of Assur (STT 1, 87);

- Nabu-ibni, a šamallû ligimûu ("youthful apprentice”), son of the Assyrian scribe Aplaya, who wrote out an unidentified medical work (STT 1, 92);

- Nabu-šum-iškun, son of Kandalanu, senior scribe of the turtannu, who copied Tablet 1 of the myth Erra and Išm (STT 1, 16), and a set of namburbuincantations and rituals against ants and other pests (STT 2, 242);

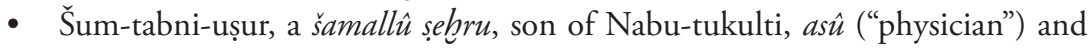
servant of the crown prince, who copied a literary work (STT 1, 36) and Abnu sikinšu, a treatise on the healing properties of stones (STT 1, 108) in the late eighth century.

It is notable that all but one of these men (Nabu-šum-iškun) describes himself as a šamallûu ("apprentice") of some sort; and that at least nine more such apprentices are attested amongst these tablets, ${ }^{6}$ plus five whose names are now missing. ${ }^{7}$ Two men, Iddi-Meslamtaea and Sum-tabni-uṣur, are contemporaries of Qurdi-Nergal, writing in the late eighth century B.C. Almost all have good connections to the scholarly or administrative life of the empire. Bel-le'u-uṣur and Nabu-šum-iškun are sons of scribes of the turtannu, Assyria's senior military officer and governor of a neighbouring province whose capital was Til-Barsip (Radner 2006-2008: 48). Šum-tabni-uṣ ur is the son of a crown prince's (i.e., Sennacherib's?) as $\hat{u}$ ("physician"); IddiMeslamtaea is a šangh-priest's son; Mutaqqin-Aššur and Nabu-ibni trace their descent to scribal families of the cities of Assur and/or Kutha. Their now-anonymous fellow-copyists seem to have similar pedigrees, including

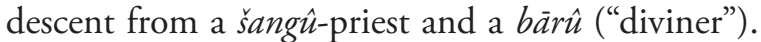

While it is of course possible that Qurdi-Nergal and his descendants acquired some or all of these men's tablets through purchase, inheritance, or exchange, their social homogeneity and mediocre scribal ability together suggest an alternative explanation. Stefan Maul (2010: 208) has recently used colophons from an assemblage of several hundred scholarly tablets, found in a seventhcentury house in the imperial city of Assur, to show that it accrued during the course of scholarly training of four generations of a family of mašmašsus ("incantation priests") associated with the temple of the city god Ašsur. In the second generation, for instance, Kișir-Aššur's titles evolved from šamallu sebru through šamallû, šamallû mašmǎ̌su șebru ("junior apprentice incantation priest"), mašmaššu șebrru ("junior incantation priest"), and mašmaššu to mašmaššu bit Aššur ("incantation priest of Ašsur's temple"). He also notes the presence of 13 tablets with colophons of men that apparently do not belong to Kișir-Aššur's family, but who are all designated as šamallûu or šamallû șehru 


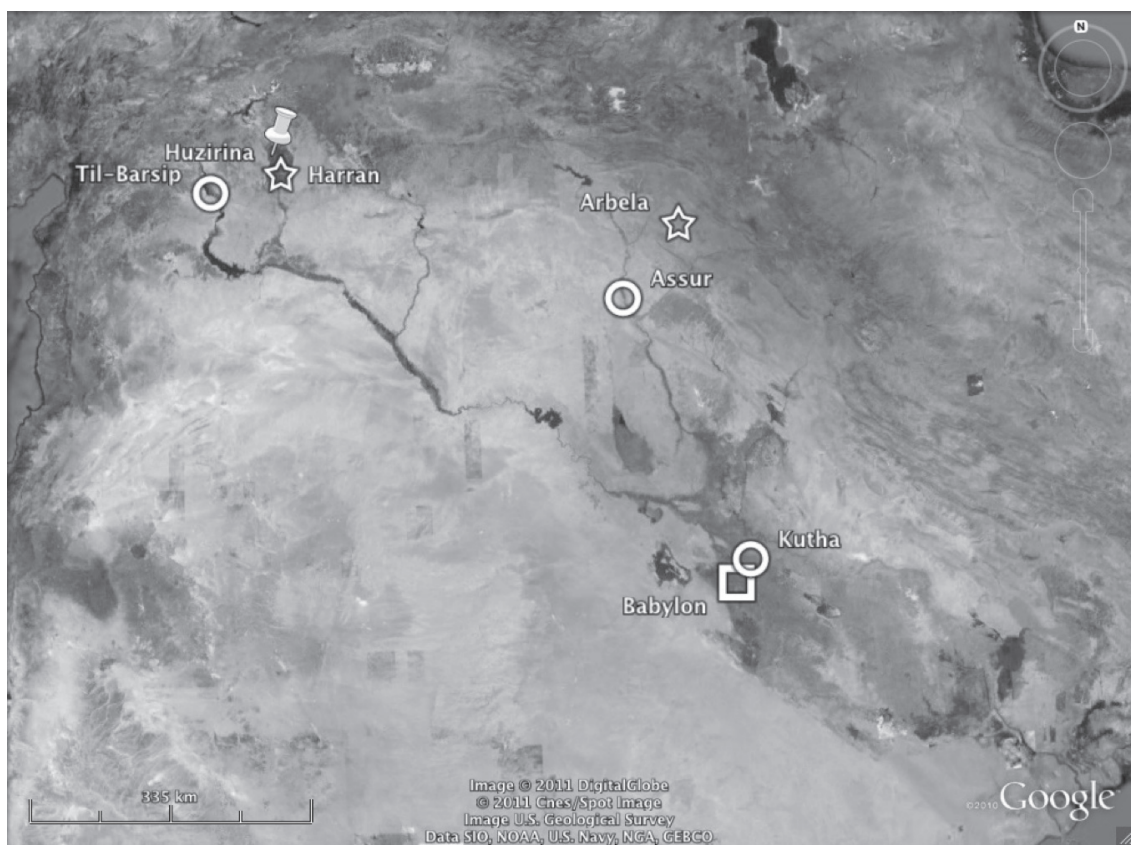

Figure 8.2. The scholarly knowledge network around seventh-century Huzirina. Key: 回 = origins of tablet originals; ( ) = origins of fathers and ancestors; $=$ locations of other temples to Zababa and Bau in the network.

too (Maul 2010: 216). Many further tablets without colophons are written in immature script, replete with errors and erasures (Maul 2010: 217). The parallels with Huzirina are compelling. Both houses, it appears, were centres of scholarly apprenticeship which attracted advanced (but not always entirely competent) learners from outside the resident family. It may be that QurdiNergal's family took in paying pupils to supplement their temple income that is documented by two fragmentary records of endowments to the temples of Zababa and Bau, and Ištar, found at Huzirina (SAA 12, 48; 91 = STT 1, 44; 2, $406+407)$. The Huzirina students were predominantly the sons of provincial officials, priests and scholars who - with the possible exception of Šum-tabni-us ur - had no direct connections to the Assyrian royal family or the inner circle of court scholars of the Ezida at Kalhu, although some belonged to families from the city of Assur (Figure 8.2).

It is not only the human actors in the Huzirina network that were not integrated into contemporary royal scholarship. While four Huzirina tablets are said to be copies from Babylon, or from the goddess Gula's temple there 
(STT 1, 73; STT 2, 136; 232; 323), none claims to be from any city of the Assyrian imperial heartland. And while Nabu was clearly central to the royal scholarly network, in Huzirina it was the divine couple Zababa and Bau of Arbela, Harran, and Huzirina, the deities served by Qurdi-Nergal and his family. However, the colophons do invoke a similar range of gods to curse or bless those who would steal or protect the tablets. In the very fragmentary Kalhu tablets only Ea and Šamaš are currently legible (CTN 4, 27; 116; 188). At Huzirina, Šamaš is invoked five out of fifteen times (STT 1, 71; 84; 92; $2,215,394)$ and Ea three times, always in conjunction with Nabu (STT 1, $38 ; 40 ; 192)$. Nabu is summoned a further three times, once together with Marduk (STT 1, 108; 2, 247; 256), while Iddi-Meslamtaea calls twice on Lugalira (STT 1, 33; 2, 159), and there are single occurrences of Adad and Zababa (STT 1, 56; 2, 199). But with the exception of the last, these deities do not seem to have particular geographical significance here but rather stand for the general or specific realms of learning with which the colophon writers wished to be associated.

\section{Uruk: A Venerable Babylonian City under Achaemenid Rule}

When the Achaemenid Persians conquered Babylonia in 539 B.C., Uruk was already about 3,000 years old. At its economic, social, and intellectual heart was a huge temple complex which had served the great sky-god An (later Anu) and his daughter the irresistible Inana (Ištar) since at least the fourth millennium B.C. Substantial property, investments, and commercial activity, as well as a flourishing offering culture, meant that - in the medium term at least - the Uruk temples could withstand the loss of royal interest and favour that came with the end of indigenous rule. Indeed, they continued to support a substantial community of learned men for several hundred years. A family of mašmašsus ("incantation priests") associated with the temples, the descendants of one Šangi-Ninurta, occupied a house in southeast Uruk until about 420 B.C., when they left behind a handful of legal records and some 190 scholarly tablets, including 56 with colophons (on the archaeology of this house, see Schmidt 1979). Medical recipes, healing rituals and incantations, and medical, terrestrial, and birth omens predominate, as might be expected of a family of healers, but mathematical and metrological works also feature (on the tablets, see Clancier 2009: 47-72, 387-405; Hunger 1976; Pedersén 1998: 212-213; von Weiher 1982, 1988, 1993, 1998; http://oracc.org/cams/ gkab/achaemenid). As in Huzirina, we can clearly identify a core group of family men plus their direct associates:

- Šamaš-iddin, mašmaššu, writer of nine scholarly tablets: four incantations and rituals, including Lamaštu and Bit rimki ("Bath house"); two collections 
of medical recipes; two commentaries on the medical omen series Sakikk $\hat{u}$ ("Ailments"); and the mathematical compilation Zèru u qanu ("Seed-measure and reed-measure") (SpTU 1, 44; 48; 3, 66; 84; 100; 4, 127; 128; 5, 254; and Friberg et al. 1990: no. 483);

- Šamaš-iddin’s son Anu-ikșur, mašmaššu (șehru) (“[junior] incantation priest”) of Anu, writer of 24 scholarly tablets: 18 for himself - 11 commentaries, three ritual series, three sets of medical recipes and a list of ingredients (SpTU $1,28 ; 31-33 ; 38 ; 45,47 ; 49-51 ; 56 ; 60 ; 72 ; 83 ; 2,8 ; 3,99 ; 5,241 ; 248)$ - plus four for his father: two incantation series, the lexical text $A n=$ Anum, and a collection of medical recipes (SpTU 1, 59; 126; 3, 69; 5, 242);

- Anu-ikșur's son Anu-ušallim, scribe of two tablets from the omen series Šumma izbu and Alandimmû (SpTU 3, 90; 4, 151) for his father;

- Šamaš-iddin's other son Rimut-Anu, a mašmašš ; copyist of a list of diseases, a set of metrological tables, and the so-called Ašipu's Handbook (SpTU 4, 152; 172; 5, 231) some time during the reign of Darius II (r. 423-405 B.C.);

- Belu-kașir, son of Balațu, apparently not a family member, who copied a list of diseases (SpTU 1, 43) for Rimut-Anu;

- Nadin, family relationship unclear, who compiled a set of arithmetical tables (SpTU 4, 174), also for Rimut-Anu;

- and two tablets - part of the lexical commentary Mur-gud and an extract from the birth omen series Šumma izbu (SpTU 1, 60; 23, 116), written by members of the Šangi-Ninurta family whose names are now lost.

A further five tablets, which are probably to be associated with this tablet collection on stratigraphic grounds, bear colophons of men who cannot be directly linked to members of the Šangi-Ninurta family:

- Anu-apal-iddin, son of Anu-šum-lišir, descendant of Kuri, copyist of a tablet of the anti-witchcraft ritual Maqlî ("Burning") (SpTU 3, 47A);

- GUBšu-Šamaš, a mašmaššu șebru and son of Ibni-Ištar, descendant of GimilNanaya, who copied a tablet of the purification ritual Bit rimki (SpTU 3, 67) for the mašmašš Ištar-nadin-ahi, son of Arad-Gula, descendant of GimilIštaran;

- Sin-banunu, a mašmaššu and son of Ilesi-Marduk, copyist of a namburb $\hat{u}$ ritual against the evil of birds entering the home (SpTU 3, 80);

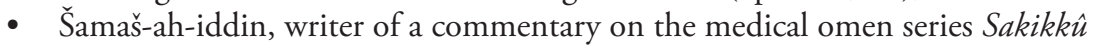
(SpTU 1, 39);

- UB-ia-[...], writer of a commentary on celestial and physiognomic omens (SpTU 1, 84).

Whether or not these tablets were produced in the Šangi-Ninurta family's house or elsewhere, it is clear from their contents, and from the professions of their copyists, that they were kept or acquired because they were all directly relevant to the family's core intellectual interests, namely healing and purification. Presumably this is how they earned their livelihood as well, but 


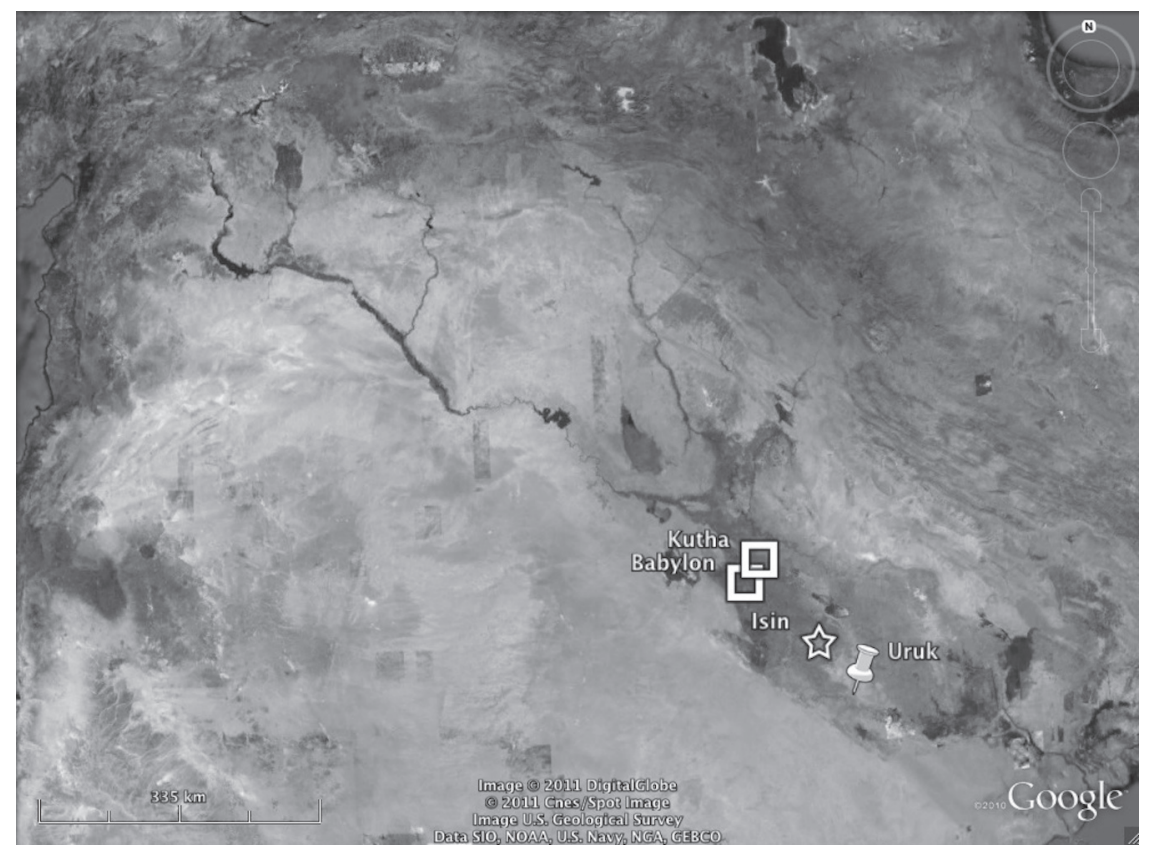

Figure 8.3. The scholarly knowledge network around fifth-century Uruk. Key: 回 = origins of tablet originals; = location of the goddess Gula's main temple.

it is also possible that the Šangi-Ninurta family held prebends, or rights to shares in temple income. Unfortunately none of the legal documents found in their house (many of which are fragmentary) mentions any of our men.

It is striking that whereas the Huzirina scribes tend to emphasize their geographical origins and/or their relationships to politically powerful patrons, the Uruk mašmašsus give only their paternity and profession. This may suggest that their scholarly network operated on a much smaller geographical scale, an impression also given by the origins of the tablets and writing boards from which they copied. Two of Šamaš-iddin's Bìt rimki tablets are said to be "a copy of a writing-board, property of the Eanna temple" in Uruk (SpTU 3, 66; 4, 127) and Anu-ikșur and Rimut-Anu both had occasion to work from "Urukean copies" (SpTU 1, 59; 3, 90; 4, 172; plus SpTU 1, 71, unsigned). There are just two extant exceptions to this localism: Anu-ikșur copied a section of Maqlù from "a tablet from among the old tablets of Meslam," a temple at Kutha (SpTU 5, 241), and Sin-banunu's namburbû stems from "a writing board from Babylon" (SpTU 3, 80) (Figure 8.3).

The divine world in which the mašmašsus operated was also much reduced. Sixteen of the 17 tablets that invoke deities in colophons call on the city 
god Anu, plus the goddess Ištar of Eanna (mostly written by Šamaš-iddin and non-family men) or Anu's divine spouse Antu (mostly by Anu-ikșur). ${ }^{8}$ Only one, by Anu-ikșur, summons Gula, the goddess of healing traditionally associated with the Babylonian city of Isin (SpTU 1, 47). Nabu, the god of wisdom so prevalent in Assyrian scholarly life, is nowhere to be seen.

\section{Conclusions}

By taking a Latourian view of cuneiform scholarship - widened to include divine as well as human and inanimate actors - and by mapping it with tools such as Google Earth, we begin to glimpse the complexities and variety under the apparently smooth surface of the "stream of tradition." The three ancient knowledge networks surveyed here each have their own distinctive characteristics, stemming from their very different scholarly and sociopolitical functions. The Ezida temple in seventh-century Kalhu was but one node in a network of scholarly repositories serving an elite group of learned men who guided Assyrian royal decision-making, and who followed king and court from city to city in the imperial heartland. The priestly household at Huzirina, by contrast, offered a gentlemanly education to the young men of empire: the offspring of scholars and provincial officials, who were proud of their origins but who aspired, perhaps, to climb further up the Assyrian social scale through acquisitions of the classics of Babylonian literature. Their network is conspicuously excluded from access to the royal cities, although it is otherwise impressively extensive. In the mašmašsus' house in fifth-century Uruk, however, we see a dramatic shrinking of the intellectual landscape that may be the outcome of late Achaemenid attitudes to Babylonian autonomy (Waerzeggers 2003-2004). While family-based learning continued in much the same way as before, scholars, apprentices, and their writings seem to have travelled rarely beyond the city limits or across professional divides. However, the Urukeans' geographical horizons were to open up again to some extent during the Seleucid period, when the Ekur-zakir family of mašmašsus, who by then were occupying the Šangi-Ninurta family's house, had access to originals from the Babylonian cities of Nippur and Der (SpTU 2, 34; 4, 125; 185) and even possessed a 300-year-old tablet from Nineveh, bearing a colophon of Assurbanipal (SpTU 2, 46).

It has also become clear that the distinction Assyriologists have traditionally made between familial and institutional tablet collections (e.g., recently Clancier 2009: 17, 319; Pedersén 1998) is not particularly meaningful: scholarly dynasties could be associated with particular institutions over many generations, and it is likely that tablets and writing boards moved as freely as their owners between homes and workplaces. Indeed, we now see that 
people, objects, and institutions were all surprisingly mobile. Individuals and groups could travel for long distances in pursuit of teachers, clients, and patrons, taking memorised as well as recorded knowledge with them. Perhaps too they travelled in search of particular learned works, for, as I have discussed elsewhere (Robson 2011, 2013), access to scholarly writings was patchy and unreliable. Instead, the composition of learned collections, while demonstrably shaped by the core intellectual interests of their creators (and deformed by the subsequent loss of perishable media), is decidedly uneven. This appears to reflect the eclectic, opportunistic acquisition of tablets and writing boards across a wide range of genres which rarely, if ever, resulted in ownership of a complete run of multi-tablet series.

Our sobering conclusion must then be that no person or community in the first millennium B.C., even the royal scholars of Nineveh, had access to as much of the so-called "stream of tradition" as we do today. And our understanding of it will only grow with the expansion of online corpora such as those that Oracc facilitates. But while previous generations understandably took their panoptic view of the whole to be a fair reflection of ancient knowledge worlds, Oracc's annotational and analytical power facilitates a more nuanced chronological, geographical, and social partition of firstmillennium intellectual space. At the same time, it breaks down the genrebased barriers erected by Assyriology over the twentieth century, allowing us new glimpses of the interrelations between different types of scholarly endeavour and some of the means by which intellectual communities cohered. But this is just the beginning: as the online Assyriological knowledge network grows and strengthens, we will be afforded many further insights - many as yet unimaginable - into the fragility and power of cuneiform scholarship in the ancient Middle East.

\section{Acknowledgements}

It is a pleasure to express my gratitude to all GKAB staff: senior research associate Graham Cunningham, research associates Marie Besnier, Philippe Clancier, Frances Reynolds, and Greta Van Buylaere, website consultant Ruth Horry, research assistant Kathryn Stevens, and the members of our editorial and historical advisory panels (see oracc.org/cams/gkab/abouttheproject). I particularly thank Heather D. Baker for her help with the Kalhu colophons discussed here (new readings now incorporated into her updates to The Prosopography of the Neo-Assyrian Empire at http://homepage.univie.ac.at/ heather.baker/pna.html), and most of all Steve Tinney, not only for his careful and perspicacious proofreading of this article but for everything he does to make our collaboration so enjoyable and rewarding. 


\section{Notes}

1. Oracc's name is a tongue-in-cheek homage to the BBC TV science fiction series Blake's 7 (1978-81), about a small group of renegade freedom fighters and their portable super-computer Orac, who battle against the evil and oppressive Terran Federation.

2. The USA and UK each accounted for 31\% of visits to K\&P in January 2011. But also in the top ten countries were the Philippines (no. 8, at 1.3\%) and India (no. 10, at $1.1 \%$ ), where no Assyriology is taught at university level. For SAAo, by contrast, the top ten for January 2011 were all North American or European countries where Assyriology is a university subject. However, the total of 33 countries included Singapore, Croatia, Brazil, Syria, Slovakia, Greece, Yemen, and Iran.

3. Šumaya son of Nabu-zeru-lešir is attested as an ǎšipu at Nineveh late in Esarhaddon's reign (SAA 10, 257; 291). Some time in 671-669 B.C. he petitioned crown prince Assurbanipal to let him take over his dead father's scholarly work at Kalhu, having established himself in a similar role in Tarbișu (SAA 16, 34). He and Adad-šumu-ușur witnessed a legal document together in the northern Assyrian town of Išpallure in 666 B.C. (SAA 6, 314).

4. Adad-šumu-ușur alone: SAA 8, 160-163; SAA 10, 185-204; 206-208; 210-211; 213-215; 217-220; 222-230; SAA 16, 167; with Nabu-zeru-lešir and/or Urad-Ea (and others): SAA 10, 1; 3; 212; 232; with other colleagues, SAA 10, 24; 205; 209; 216; 221 231; 256; 259; Nabu-zeru-lešir alone: SAA 10, 2; SAA 16, 50; Urad-Ea alone or with others: SAA 8, 181-183; SAA 10, 25; 338-344.

5. The two remaining extant names are both very fragmentary: Bel-[..], copyist of birth omens (CTN 4, 31); Nabu-[..], mentioned in the colophon of an unknown incantation (CTN 4, 125); there is also a šamallu sebru ("junior apprentice"), copyist of the astronomical compendium Mul-apin "Plough star" (CTN 4, 27), whose name is now missing.

6. The other named scribes are the šamallû șebrūtu ("junior apprentices”) Aššur-šumuiddina, Bel-ašaredu, Išdi-ilu, Marduk-ban-[..], Nabu-ețir, Nabu-šabši, [...]-ereš, and [..]-šum-ikṣur (STT 1, 57; 73; 84; 85; 2, 136; 256; 340; 368); the šamallû [..]-zeribni and Sin-šumu-iddin, both sons of scribes (STT 1, 82; 109); and - with no titles given - Mannu-ki-Babili, Nabu-ețir-napšate, Nabu-ețiranni, Nabu-ahhe-šallim, and Sin-iddina (STT 1, 3; 10; 2, 215; 232; 241; 301; 330). In addition Bel-šar-ahhešu, a [priest] of Aššur's temple in Assur, and Marduk-šapik-zeri, an āšipu from Babylon, are mentioned in one colophon each, but apparently not as copyists or owners (STT $1,69 ; 89)$.

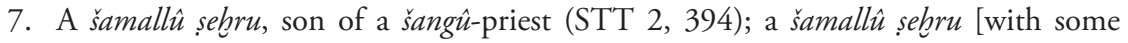
relationship to] Iddi-Meslamtaea (STT 2, 390); a šamallû sebru, son of the scribe and bāru ("diviner") Marduk-ban-apli (STT 1, 70); and one or more further šamall $\hat{u}$ (sebr[üt]u) (STT 1, 55; 66; STT 2, 343).

8. Anu and Ištar: SpTU 1, 48; 59; 3, 69, 84 (Šamaš-iddin), SpTU 1, 45; 5, 241 (Anuikșur), SpTU 1, 39 (Šamaš-ah-iddin) and SpTU 3, 74A (Anu-apal-iddin); Anu and Antu: SpTU 1, 126; 5, 254 (Šamaš-iddin), SpTU 1, 33; 2, 8; 3, 90; 5, 242; 248 (Anu-ikșur); Anu and [..]: SpTU 4, 152 (Rimut-Anu). 


\section{References}

Black, Jeremy

2008 The Libraries of Kalhu. In New Light on Nimrud: Proceedings of the Nimrud Conference, 11th-13th March 2002, edited by John E. Curtis, Henrietta McCall, Dominique Collon, and Lamia al-Gailani Werr, pp. 261-266. British Institute for the Study of Iraq, London.

Black, Jeremy, Graham Cunningham, Eleanor Robson, and Gábor Zólyomi 2004 The Literature of Ancient Sumer. Oxford University Press, Oxford.

Chavalas, Mark W. (editor)

2006 The Ancient Near East: Historical Sources in Translation. Blackwell, Oxford.

Clancier, Philippe

2009 Les bibliothèques en Babylonie dans la deuxième moitié du Ier millénaire av. J.-C. Ugarit-Verlag, Münster.

CTN 4 = Wiseman and Black 1996

Editions of individual texts online at http://oracc.org/cams/gkab/ctn_4_0 (replacing 0 with the text number).

Curtis, John E., Henrietta McCall, Dominique Collon, and Lamia al-Gailani Werr (editors)

2008 New Light on Nimrud: Proceedings of the Nimrud Conference, 11th-13th March 2002. British Institute for the Study of Iraq, London.

Ebeling, Erich

1919-1923 Keilschrifttexte aus Assur religiösen Inhalts. 2 vols. J.C. Hinrichs, Leipzig.

Foster, Benjamin R.

2005 Before the Muses: An Anthology of Akkadian Literature. 3rd edition. CDL Press, Bethesda, Maryland.

Friberg, Jöran, Hermann Hunger, and Farouk N. H. Al-Rawi

1990 "Seed and Reeds": A Metro-Mathematical Topic Text from Late Babylonian Uruk. Baghdader Mitteilungen 21: 483-557. Edition online at http://oracc.org/cams/gkab/ bagm_21,_483/.

Gurney, Oliver R.

1952 The Sultantepe Tablets: A Preliminary Note. Anatolian Studies 2: 25-35.

1997 Scribes at Huzirina. Nouvelles Assyriologiques Brèves et Utilitaires 1997(1): 18, no. 18.

Gurney, Oliver R., and Jacob J. Finkelstein

1957 The Sultantepe Tablets, Vol. 1. British Institute of Archaeology at Ankara, London.

Gurney, Oliver R., and Peter Hulin

1964 The Sultantepe Tablets, Vol. 2. British Institute of Archaeology at Ankara, London.

Hunger, Hermann

1968 Babylonische und assyrische Kolophone. Butzon and Bercker, Kevelaer; Neukirchener Verlag des Erziehungsvereins, Neukirchen-Vluyn.

1976 Spätbabylonische Texte aus Uruk, Vol. 1. Mann, Berlin.

KAR = Ebeling 1919-1923

Latour, Bruno

1987 Science in Action: How to Follow Scientists and Engineers through Society. Harvard University Press, Cambridge. 
Lloyd, Seton

1954 Sultantepe, Part II. Post-Assyrian Pottery and Small Objects Found by the AngloTurkish Joint Expedition in 1952. Anatolian Studies 4: 101-110.

Lloyd, Seton, and Nuri Göçke

1953 Sultantepe: Anglo-Turkish Joint Excavations, 1952. Anatolian Studies 3: 27-47.

Loud, Gordon, and Charles B. Altman

1938 Khorsabad, Part 2: The Citadel and the Town. The Oriental Institute of the University of Chicago, Chicago.

Mallowan, Max Edgar Lucien

1966 Nimrud and Its Remains. 2 vols. Collins, London.

Maul, Stefan M.

2010 Die Tontafelbibliothek aus dem sogenannten "Haus des Beschwörungspriesters." In Assur-Forschungen: Arbeiten aus der Forschungsstelle "Edition literarischer Keilschrifttexte aus Assur" der Heidelberger Akademie der Wissenschaften, edited by Stefan M. Maul and Nils P. Heeßel, pp. 189-228. Harrassowitz, Wiesbaden, Germany.

Oates, Joan, and David Oates

2001 Nimrud: An Assyrian Imperial City Revealed. British School of Archaeology in Iraq, London.

Oxford English Dictionary Online

2013 black box, n. OED Online, September 2013, Oxford University Press, electronic document, http://www.oed.com/view/Entry/282116? redirectedFrom=black+box\&, accessed September 25, 2013.

Oppenheim, A. Leo

1960 Assyriology: Why and How? Current Anthropology 1: 409-423.

Parpola, Simo

1983 Assyrian Library Records. Journal of Near Eastern Studies 42: 1-29.

Pedersén, Olof

1998 Archives and Libraries in the Ancient Near East, 1500-300 B.C. CDL Press, Bethesda, Maryland.

Pritchard, James B.

1950 Ancient Near Eastern Texts Relating to the Old Testament. Princeton University Press, Princeton.

Radner, Karen

2006-2008 Provinz. C. Assyrien. In Reallexikon der Assyriologie, Vol. 11, edited by Michael P. Streck, pp. 42-68. De Gruyter, Berlin.

2011 Royal Decision-Making: Kings, Magnates and Scholars. In The Oxford Handbook of Cuneiform Culture, edited by Karen Radner and Eleanor Robson, pp. 358-379. Oxford University Press, Oxford.

Reade, Julian E.

1998-2001 Ninive (Nineveh). In Reallexikon der Assyriologie, Vol. 9, edited by Dietz O. Edzard, pp. 388-433. De Gruyter, Berlin.

Robson, Eleanor

2011 The Production and Dissemination of Scholarly Knowledge. In The Oxford 
Handbook of Cuneiform Culture, edited by Karen Radner and Eleanor Robson, pp. 557-576. Oxford University Press, Oxford.

2013 Reading the Libraries of Assyria and Babylonia. In Ancient Libraries, edited by Jason König, Katerina Oikonomopoulou, and Greg Woolf, pp. 38-56. Cambridge University Press, Cambridge.

Robson, Eleanor, and Kathryn Stevens

in press Tablet Collections in First-Millennium Assyria and Babylonia. In The Earliest Libraries: Library Tradition in the Ancient Near East from the Dawn of History until the Roman Era, ca. 3200 B.C.-200 A.D., edited by Kim Ryholt and Gojko Barjamovic. Oxford University Press, Oxford.

SAA $\quad=$ State Archives of Assyria

Editions of individual texts online at http://oracc.org/saao/saa_n_m (replacing " $n$ " with the volume number and " $\mathrm{m}$ " with the text number).

Schmidt, Jürgen (editor)

1979 XXIX. und XXX. vorläufiger Bericht über die von dem Deutschen Archäologischen Institut aus Mitteln der Deutschen Forschungsgemeinschaft unternommenen Ausgrabungen in Uruk-Warka 1970/71 und 1971/72. Mann, Berlin.

SpTU = Hunger 1967; von Weiher 1982, 1988, 1993, 1998

Editions of individual texts online at http://oracc.org/cams/gkab/sptu_n_m (replacing " $\mathrm{n}$ " with the volume number and " $\mathrm{m}$ " with the text number).

STT = Gurney and Finkelstein 1957; Gurney and Hulin 1964

Editions of individual texts online at http://oracc.org/cams/gkab/stt_n_m (replacing " $n$ " with the volume number and " $m$ " with the text number).

Veldhuis, Niek

2006 How Did They Learn Cuneiform? "Tribute/Word List C" as an Elementary Exercise. In Approaches to Sumerian Literature in Honour of Stip (H.L.J. Vanstiphout), edited by Piotr Michalowski and Niek Veldhuis, pp. 181-200. Brill, Leiden.

Weiher, Egbert von

1982 Spätbabylonische Texte aus Uruk, Vol. 2. Mann, Berlin.

1988 Spätbabylonische Texte aus Uruk, Vol. 3. Mann, Berlin.

1993 Spätbabylonische Texte aus Uruk, Vol. 4. Verlag Philipp von Zabern, Mainz am Rhein.

1998 Spätbabylonische Texte aus Uruk, Vol. 5. Verlag Philipp von Zabern, Mainz am Rhein.

Waerzeggers, Caroline

2003-2004 The Babylonian Revolts Against Xerxes and the "End of Archives." Archiv für Orientforschung 50: 150-173.

Wiseman, Donald J.

1955 Assyrian Writing-Boards. Iraq 17: 3-13.

Wiseman, Donald J., and Jeremy Black

1996 Cuneiform Texts from Nimrud, Vol. 4: Literary Texts from the Temple of Nabû. British School of Archaeology in Iraq, London. 